\title{
Az anterográd technikák szerepe a krónikus teljes koszorúér-elzáródás perkután revaszkularizációjában
}

\author{
Tajti Péter ${ }^{1,2}$, Ungi Imre
}

\author{
'Szegedi Tudományegyetem, Invazív Kardiológiai Részleg, II. Sz. Belgyógyászati Klinika és \\ Kardiológiai Központ, Szeged \\ ${ }^{2}$ Minneapolis Heart Institute, Abbott Northwestern Hospital, Minneapolis, Minnesota, Egyesült Államok \\ Levelezési cím: \\ Dr. Ungi Imre PhD, Szegedi Tudományegyetem, Invazív Kardiológiai Részleg, II. sz. Belgyógyászati Klinika és Kardiológiai \\ Központ, 6725 Szeged, Semmelweis u.6., e-mail: ungi.imre@gmail.com
}

\begin{abstract}
A krónikus teljes koszorúér-elzáródás perkután koronáriaintervenciója rohamos fejlödésen ment keresztül az elmúlt évtized alatt, amelynek következtében a dedikált CTO-centrumok beavatkozási sikeraránya jelentősen javult alacsony szövődményráta mellett. Sikeres CTO PCI a megfelelően megválasztott esetekben jelentős javuláshoz segíti a betegeket, ugyanakkor a CTO-revaszkularizációnak továbbra is a legnagyobb kihívása az okklúzió megnyitása. A széles körben alkalmazott technikák magukba foglalják az anterográd dróteszkaláció, az anterográd disszekció és re-entry, valamint a retrográd technikákat. Anterográd dróteszkaláció továbbra is a leggyakrabban alkalmazott, és legtöbb esetben sikeres technika, az anterográd disszekció re-entry és a retrográd technikákat föleg komplex léziók esetén alkalmazzuk. Cikkünk célja, hogy átfogó képet adjunk a jelenkori anterográd technikákról és eszközökről, amelyek elősegítik a vezetődrót átjutását az okklúzión.

Kulcsszavak: krónikus teljes koszorúér-elzáródás, perkután koronária-intervenció, stabil koronáriabetegség, komplex koronária-intervenció

The Role of Antegrade Techniques in Current Practice of Percutaneous Coronary Interventions for Chronic Total Occlusions

Chronic total occlusion (CTO) percutaneous coronary intervention (PCI) has been rapidly evolving with high success and acceptable complication rates currently being achieved at dedicated high-volume centers. Successful CTO PCI in appropriately selected patients can provide significant clinical benefits, however crossing the occlusion with a guidewire can be challenging. The following techniques can be used for CTO crossing: antegrade wire escalation, antegrade dissection/re-entry and the retrograde approach. Antegrade wire escalation remains the most frequently used technique and is the most common final successful technique, especially in less complex CTOs. Antegrade dissection re-entry and the retrograde approach are more technically demanding, but are often necessary to achieve crossing, in complex CTOs. In this manuscript, we provide a comprehensive overview of antegrade wire crossing of coronary CTOs.
\end{abstract}

Keywords: chronic total occlusion, percutaneous coronary intervention, stable coronary artery disease, complex coronary intervention

A krónikus teljes koszorúér-elzáródás (CTO) definíció szerint a koronária lumenének teljes (TIMI [Thrombolysis In Myocardial Infarction] flow 0) elzáródása, amely fennállásának időtartama minimum három hónap koronarográfiával, vagy annak hiányában a klinikai kép alapján alátámasztva. A CTO incidenciája 18-52\% közötti azon betegekben, akik diagnosztikus szívkatéterezésen esnek át koronáriabetegség tisztázása céljából
(1-4), ugyanakkor ezen betegek nagyobb része konzervatív gyógyszeres terápiában vagy mütéti revaszkularizációban részesül, csupán kis hányadukban végeznek perkután koronáriaintervenciót $(\mathrm{PCI})(5)$. Ennek az alacsony aránynak lehetséges magyarázatai között szerepel a korlátozott intervenciós tapasztalat CTO PCI terén, a magasabb költségek, a relatíve hosszú beavatkozások miatti katéteres laborzsúfoltság, az átlagos in- 
tervenciókét meghaladó szövődményráta, és a továbbra is ellentmondásos kép a CTO-revaszkularizációnak klinikai hasznáról.

Az elmúlt években a CTO PCI technikája jelentős fejlődésen ment keresztül bizonyítva, hogy specializált centrumokban az esetek 85-90\%-ában sikeres revaszkularizáció érhető el alacsony periprocedurális kompli- káció rátával (3\%) (6-9). A legnagyobb technikai kihívást továbbra is a vezetődrót átjuttatása jelenti a distalis valódi lumen felé $(10,11)$, ami nem specializált centrumokban csak 50-60\%-os sikerarányt eredményez (4, 12, 13).

Az anginás panaszokkal, illetve szívelégtelenség tüneteivel élő betegek nagy száma miatt a krónikus teljes

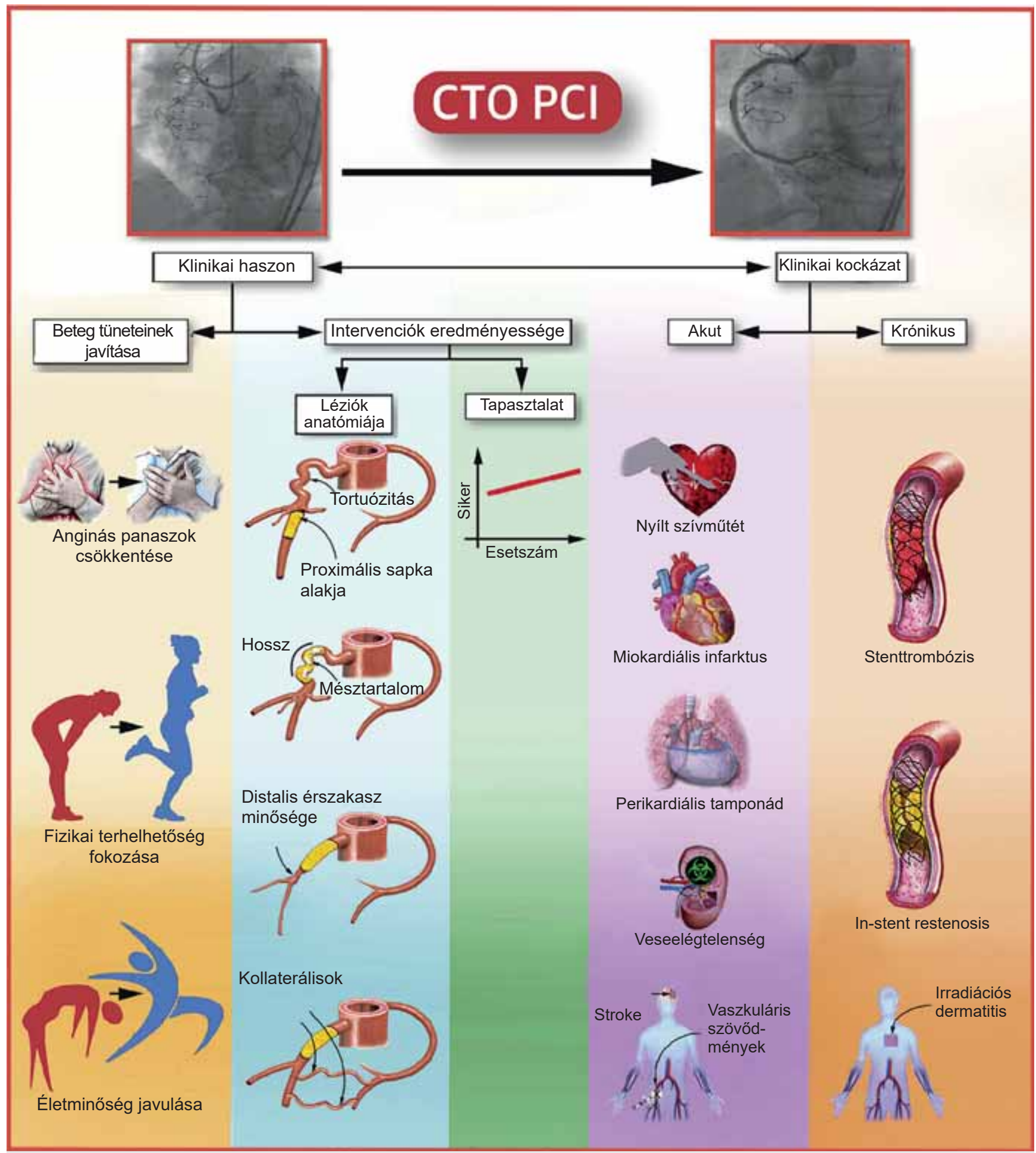

1. ÁBRA. Kockázat-haszon arány klinikai felbecslése a krónikus teljes koszorúér-elzáródások perkután koronária-intervenciója során (14) 
koszorúér-elzáródás perkután revaszkularizációja iránti igény emelkedik, amely több dedikált CTO-centrum kialakítását igényli hazánkban is. Az elmúlt évek technikai fejlődése elsősorban a jelenkori anterográd CTO rekanalizációs technikák elterjedését eredményezte, amelyek rutinszerü elsajátítása fontos sarokköve a sikeres CTO-program elindításának.

\section{Esetválasztás}

Egy adott centrum és operatőr felkészültségével arányos komplexitású esetek megválasztása kritikus az intervenció sikere és biztonsága szempontjából, így a kockázat-haszon arány mérlegelése az első fontos lépés az intervenciót megelőzően (1. ábra) (14). Az elzáródás $\mathrm{PCl}$-vel megoldhatóságának felmérését 4 fő kérdés köré kell csoportosítanunk:

- milyen klinikai javulás várható a sikeres CTO PCl elvégzését követően,

- mekkora a valószínüsége a beavatkozás sikerének az angiográfiás kép és a rendelkezésre álló eszköztár alapján,

- az operatőrök képzettsége megfelelő-e (2. ábra), valamint
- a beavatkozási szövődmények esélyének mérlegelése.

\section{CTO komplexitás}

Számos pontozási rendszert validáltak és közöltek az elmúlt évek alatt a CTO-intervenciók várható kimenetelének megítélésére (J-CTO Score [15], CL Score [16], PROGRESS CTO Score [17], ORA Score [18], RECHARGE Score [19], és az Ellis Score [20]). Ezek a pontrendszerek különböző klinikai és angiográfiás faktorokat ötvöznek az eset komplexitásának és a beavatkozás nehézségének becslésére (1. táblázat) (15-21). Jelenleg a legáltalánosabban elterjedt és validált pontrendszer a J-CTO Score (22-24), amely segítségével megjósolható a vezetődrót distalis lumenbe juttatásának esélye 30 percen belül 5 alapvető paraméter figyelembevételével (lézióhossz >20 $\mathrm{mm}, 45^{\circ}$-os lézió tortuozitás, meszesedés angiográfiás jelei, a proximális sapka alakja [V-alakú vagy tompa], és korábbi sikertelen CTO intervenció).

A CTO pontrendszerek alkalmazása fontos lehet több szempontból is:

- felmérik a speciális rekanalizációs technikák szükségességet (anterográd disszekció és re-entry [ADR] és/vagy retrográd technikák) (3. ábra);

\section{TÁBLÁZAT. A jelenleg elérhető CTO pontozási rendszerek}

\begin{tabular}{|c|c|c|c|c|c|c|c|}
\hline Tényezök & $\begin{array}{c}\text { J-СТО } \\
\text { score (15) }\end{array}$ & $\begin{array}{l}\text { CL score } \\
\text { (16) }\end{array}$ & $\begin{array}{c}\text { PROGRESS } \\
\text { CTO score } \\
\text { (17) }\end{array}$ & $\begin{array}{c}\text { ORA score } \\
(18)\end{array}$ & $\begin{array}{l}\text { RECHARGE } \\
\text { score (19) }\end{array}$ & $\begin{array}{c}\text { Ellis core } \\
(20)\end{array}$ & $\begin{array}{l}\text { PROGRESS } \\
\text { CTO Comp- } \\
\text { lications } \\
\text { score }(21)\end{array}$ \\
\hline Esetszám (n) & 494 & 1,657 & 781 & 1,073 & 1,253 & 456 & 1589 \\
\hline Végpont & $\begin{array}{l}\text { Drót eszkala- } \\
\text { ció <30 min }\end{array}$ & $\begin{array}{l}\text { Angiográfiás } \\
\text { siker }\end{array}$ & $\begin{array}{l}\text { Angiográfiás } \\
\text { siker }\end{array}$ & $\begin{array}{l}\text { Angiográfiás } \\
\text { siker }\end{array}$ & $\begin{array}{l}\text { Angiográfiás } \\
\text { siker }\end{array}$ & $\begin{array}{l}\text { Angiográfiás } \\
\text { siker }\end{array}$ & $\begin{array}{l}\text { Periproce- } \\
\text { durális } \\
\text { komplikáciok }\end{array}$ \\
\hline Életkor (év) & - & - & - & $+(\geq 75)$ & $+(>65)$ & - & $+(>65)$ \\
\hline $\begin{array}{l}\text { Korábbi } \\
\text { CABG }\end{array}$ & - & + & - & - & + & - & - \\
\hline $\begin{array}{l}\text { Korábbi siker- } \\
\text { telen kísérlet }\end{array}$ & + & - & - & - & - & - & - \\
\hline $\begin{array}{l}\text { Proximális } \\
\text { sapka }\end{array}$ & $+($ Tompa $)$ & $+($ Tompa $)$ & + (Homályos) & + (Ostialis) & + & $\begin{array}{c}+ \text { (Homályos, } \\
\text { ostialis })\end{array}$ & - \\
\hline Tortuózitás & $\begin{array}{c}+\left(>45^{\circ}\right. \\
\text { okkludált } \\
\text { szegmentben })\end{array}$ & - & $\begin{array}{c}\text { + (okkludált } \\
\text { szegmenttől } \\
\text { proximali- } \\
\text { san†) }\end{array}$ & - & + & + & - \\
\hline Meszesedés & + & + & - & - & + & + & - \\
\hline Lézió hossz & $+(\geq 20 \mathrm{~mm})$ & $+(\geq 20 \mathrm{~mm})$ & - & - & + & + & $+(>23 \mathrm{~mm})$ \\
\hline Okkludált ér & - & $+($ nem-LAD) & $+(\operatorname{LCX})$ & - & - & $\begin{array}{c}\text { + (Kedvezőt- } \\
\text { len distalis } \\
\text { érszakasz) }\end{array}$ & - \\
\hline $\begin{array}{l}\text { Kollaterálisok } \\
\text { minősége }\end{array}$ & - & - & $\begin{array}{l}+ \text { (Interven- } \\
\text { ciós) }\end{array}$ & $\begin{array}{c}+ \text { (Rentrop } \\
<2)\end{array}$ & - & + & - \\
\hline Egyéb & - & $\begin{array}{c}\text { Korábbi } \\
\text { miokardiális } \\
\text { infarktus }\end{array}$ & - & - & $\begin{array}{l}\text { BMI }>30, \text { nem } \\
\text { proximalis } \\
\text { lokáció }\end{array}$ & $\begin{array}{c}\text { CTO } \\
\text { intervenciós } \\
\text { tapasztalat }\end{array}$ & $\begin{array}{c}\text { Retrográd } \\
\text { technika } \\
\text { alkalmazása }\end{array}$ \\
\hline
\end{tabular}




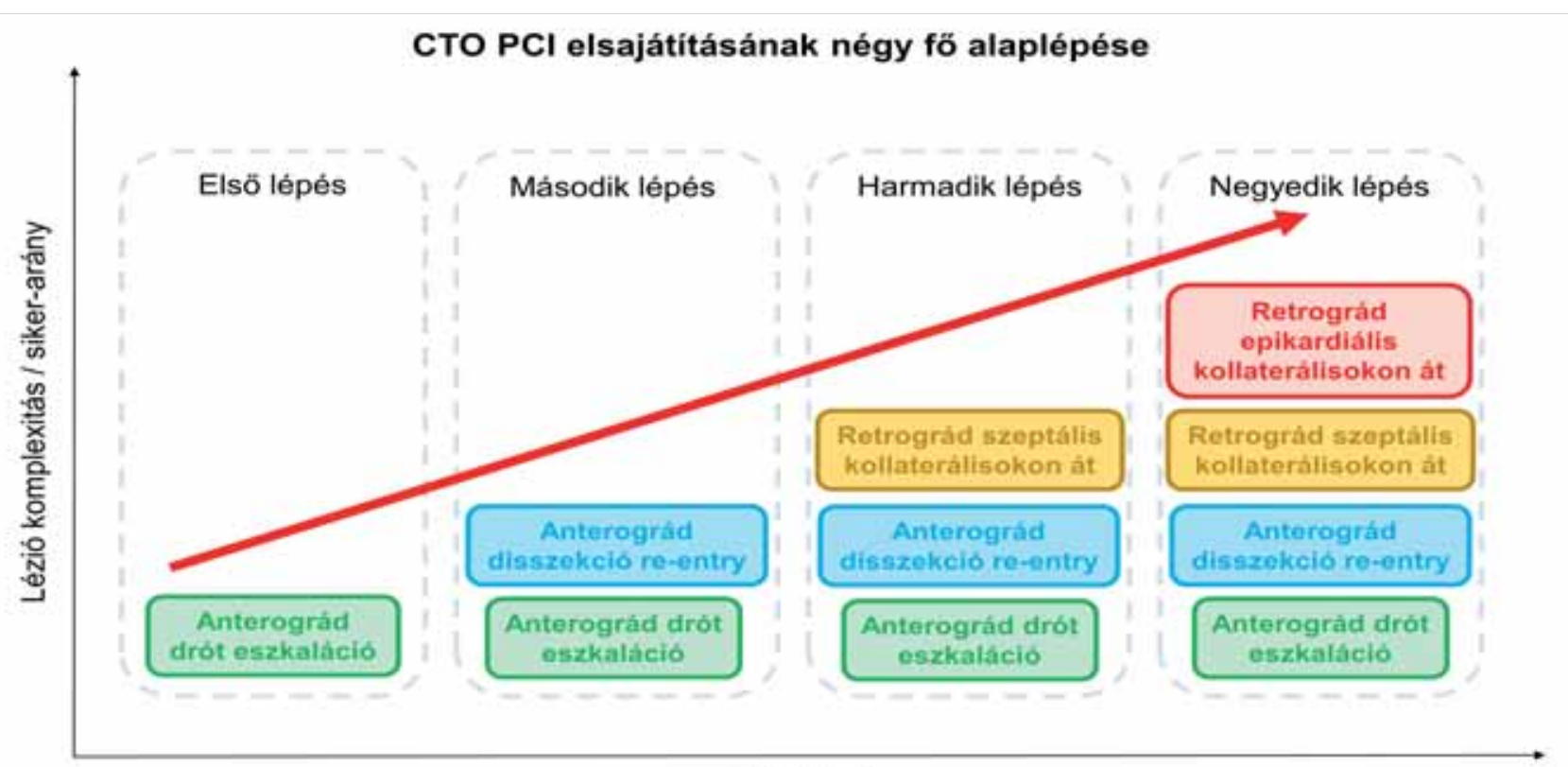

\section{Esetszám}

2. ÁBRA. A krónikus teljes koszorúér-elzáródás perkután intervenció elsajátításának négy alapvető lépése

- beavatkozás sikeres kimenetelének predikciója a rendelkezésre álló eszközök és intervenciós tapasztalati adottságok alapján (25), valamint

- az intervenció időigényének becslésére (több magas komplexitású eset egy napra történő tervezése jelentősen megterhelheti a centrum emberi erőforrásait) (26).

A CTO pontrendszerek rutinszerü alkalmazásának kritikus szerepe van az anterográd technikák sikerének becslésében továbbá a beavatkozások megtervezésében, valamint a beteg előzetes tájékoztatásában is.

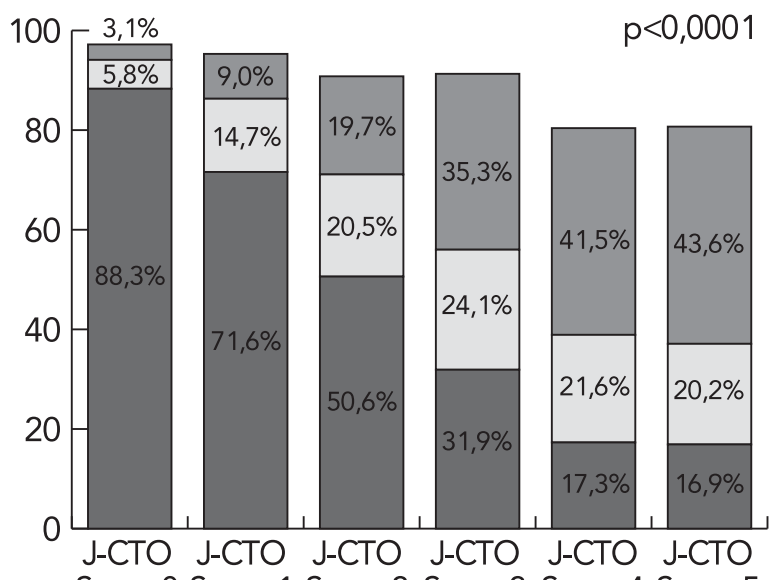

Score 0 Score 1 Score 2 Score 3 Score 4 Score 5
$\square$ AWE
$\square$ ADR
$\square$ Retrográd

3. ÁBRA. Sikeres revaszkularizációs technikák megoszlása a lézió komplexitásának függvényében a J-CTO score alapján (6)

\section{A technika megválasztása}

Az optimális elsődleges és az azt követő intervenciós stratégiák kiválasztása a koronária, illetve az okklúzió anatómiájának alapján kulcsfontosságú a beavatkozás sikeréhez (27). Igen lényeges az angiográfiás kép alapos tanulmányozása (szükség szerint akár 15-20 percig) az intervenciót megelőzően. A krónikus teljes okklúzió patomorfológiai (4. ábra) felépítése, azaz a proximális sapka alakja és mésztartalma, a mikrocsatornák jelenléte, valamint a distalis sapka morfológiája és a distalis érszakasz minősége alapvető az intervenció megtervezéséhez. Az okklúzió anatómiájának precíz és megfelelő vizualizációjához az esetek legnagyobb hányadában szimultán ipsilaterális és kontralaterális kontraszt-injekció („dual angiography”) szükséges, amelynek során nagyítás és a képmező mozgatása nélkül megfelelő hosszúságú felvételeket kell készítenünk. Alternatív lehetőség a mikrokatéterbe adott kontrasztanyag („tip injection”) a distalis érszakasz vizualizálására (5. ábra), főleg ha elsősorban ipsilaterális epikardiális kollaterálisok dominálnak -

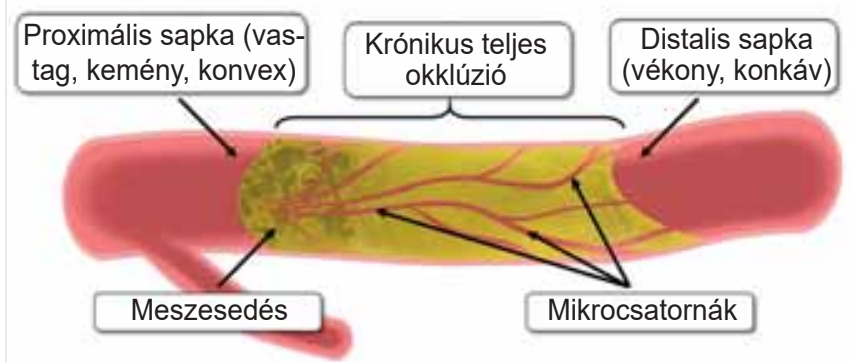

4. ÁBRA. A krónikus teljes koszorúér-elzáródások morfológiájának sematikus felépítése 


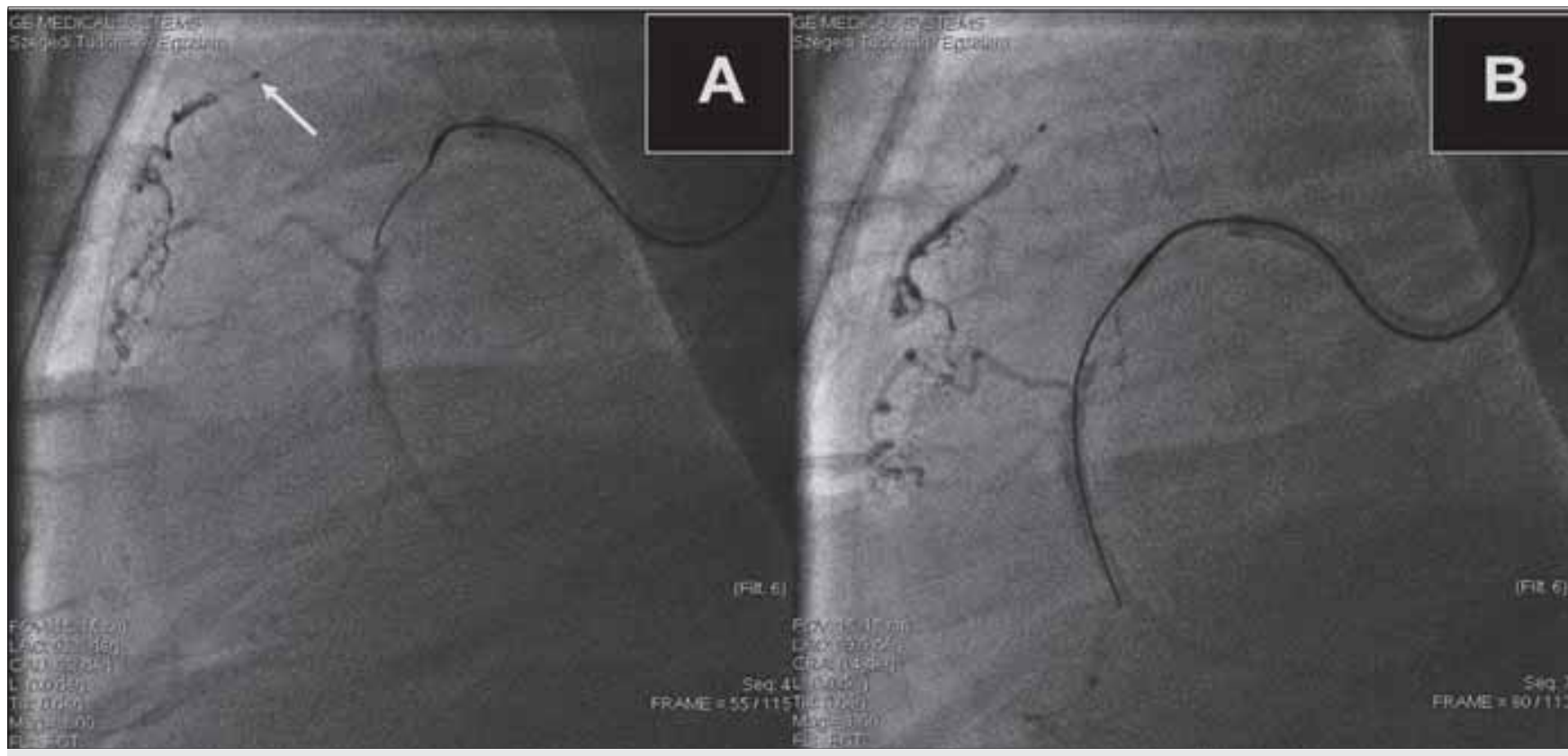

5. ÁBRA. Ipsilateralis szimultán kontraszt injekció vezérelte anterográd CTO-revaszkularizáció

ugyanakkor kontralaterális, kollaterális hálózat feltérképezése esetén a konvencionális kontralaterális injekció eredményesebb képet adhat.

Jelenleg két algoritmus érhető el a klinikai gyakorlatban, amely segítséget nyújt a CTO rekanalizációs stratégia megválasztásában:

- a hibrid algoritmus (27) és az

- Asia Pacific algoritmus (28).

A hibrid algoritmus (6. ábra) bilaterális injekció segítségével 4 anatómiai tulajdonságra fókuszálva (proximális sapka alakja, distalis érszakasz minősége, intervenciós kollaterálisok jelenléte, és a lézió hoszszúsága [> vagy <20 mm]) tesz javaslatot a kezdő stratégia megválasztására (anterográd/retrográd, vezetődrót-eszkaláció/disszekció re-entry) (29). A hibrid algoritmus lényege a szükség esetén gyors és rugalmas intervenciós - anterográd és retrográd - straté- giák alkalmazása (a kezdő technika csupán az esetek 50-60\%-ában eredményes), amely emeli revaszkularizációk sikerességet (6).

Az Asia Pacific algoritmus elsősorban az intra-plakk rekanalizációs szemléletmódot képviseli, azaz kevésbé támaszkodik a disszekció-re-entry technikákra. Ez a stratégia - szemben a hibrid algoritmussal - intravaszkuláris ultrahang (IVUS) vagy CT-angiográfia (CTA) gyakori alkalmazását igényli (28).

Bilaterális kontraszt injekció alkalmazása kritikus az okklúzió és a kollaterális hálózat anatómiájának megítélésében, amelyet szinte minden CTO PCI esetében rutinszerúen ajánlott elvégezni. Algoritmikus stratégiaválasztás és a rendelkezésre álló technikák alternáló használata növeli a CTO-intervenció sikeresélyét valamint segíti az ad hoc döntések elkerülését a beavatkozás alatt.

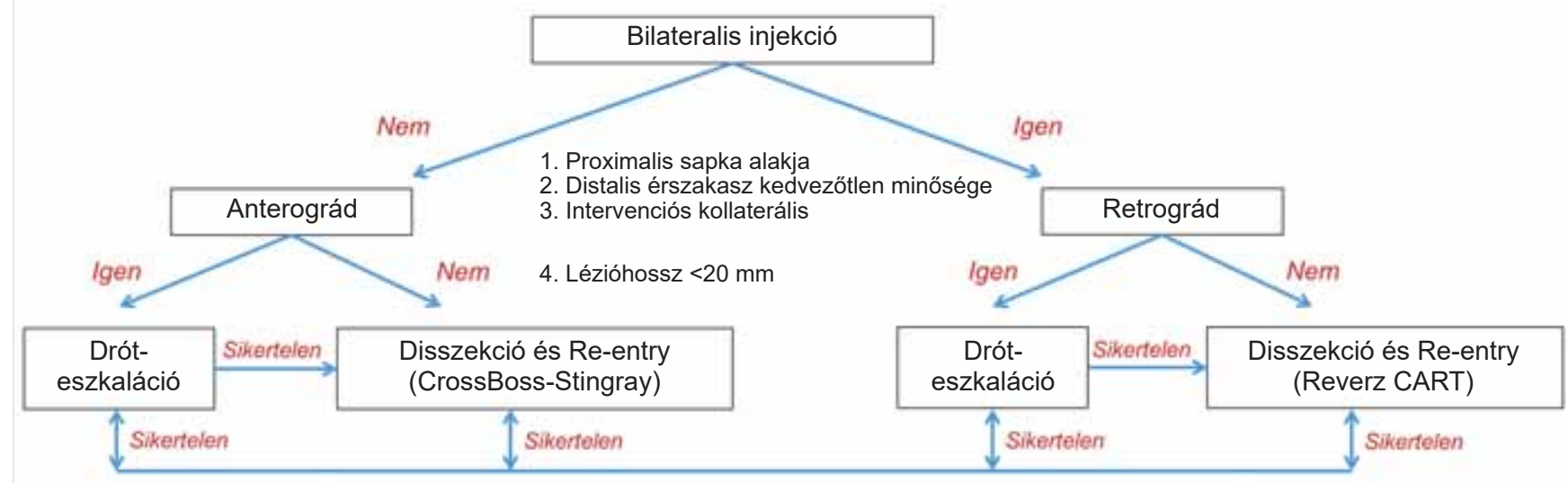

6. ÁBRA. A hibrid algoritmus (14) 


\section{Anterográd dróteszkalációs (antegrade wire escalation [AWE]) technikák}

Az anterográd dróteszkaláció a jelenkori CTO intervenciós gyakorlatban az alapvető, és legelterjedtebben alkalmazott technika, amelynek hatékonysága föleg kevésbé komplex okklúziók esetén jelentős. Ismerete és biztonságos alkalmazása a különböző bonyolultabb technikák (ADR és retrográd) elsajátításának is alapját képezi (3. ábra). Az AWE-technika alkalmazása optimális a rövid $(<20 \mathrm{~mm})$, egyenes, és mikrocsatornákat tartalmazó elzáródások esetén (4. ábra).

\section{Eszközők és a behatolási kapu megválasztása}

A megfelelő katéterszupport biztosítása rendkívül fontos a CTO-intervenciókban, hiszen ez jelentősen képes javítani a vezetődrótok penetrációs képességét. A megfelelő szupport biztosítására számos technika áll rendelkezésére:

- nagy átmérőjủ vezetőkatéterek,

- mikrokatéterek,

- extenziós katéterek vagy

- a különböző horgonyzó technikák.

\section{Radiális vs. femoralis behatolás}

A koszorúér-intervenciók többségében ma általánosan elfogadott a radiális behatolás elsődleges alkalmazása. CTO $\mathrm{PCl}$ esetén nem ennyire egyértelmú a kérdés megválaszolása, hiszen általánosan elfogadott tény, hogy az elérhető és a beteg által tolerált legnagyobb belső átmérőjű, vezetőkatéter a preferálandó, amely számos esetben femorális behatolást tesz szükségessé. A 7-8 F (French) transfemoralis vezetőkatéterek használata a leggyakrabban javasolt (lehetöleg hosszú, $45 \mathrm{~cm}$-es sheath használatával), amely optimális szupportot biztosít, ugyanakkor e katéterekkel a vaszkuláris szövődmények esélye is magasabb (30). Ultrahang-vezérelte punkció (31) és/vagy fluoroszkópiás ellenőrzés mellett (32) csökkenthetö a perifériás komplikációk kialakulásának esélye, ha az operatör a femoralis artéria használata mellett dönt. Ezzel szemben számos CTO-operatör kombinált radialis-femoralis vagy bilaterális radiális beavatkozást alkalmaz, amely a $7 \mathrm{~F}$ "slender sheath" (Terumo, Somerset, New Jersey) alkalmazásával elegendő belső diamétert és támasztékot biztosíthat. A „hibrid vaszkuláris” szemlélet elterjedése, azaz a kombinált radialis és femoralis behatolás jó megoldás az esetek többségében, mivel a nagy átmérőjű femoralis vezetőkatéter megfelelő anterográd szupportot ad, míg a radialisan feljuttatott katéter (kisebb átmérőjú sheath [6-7 F]) elegendő teret biztosít a retrográd eszközök felvezetéséhez (33).

\section{Mikrokatéterek}

Mikrokatéterek a CTO-intervencióban minden esetben alkalmazandóak, mint a legegyszerübb, de egyben leghatékonyabb megoldás a vezetődrót penetrációs ké- pességének javítására. A mikrokatéterek a vezetődrót végének formálását/újra formálását, és kicserélését is lehetővé teszik a pozíció elvesztése nélkül. Jelen gyakorlatban az over-the-wire (OTW) ballonkatéterek alkalmazása mikrokatéterek helyett nem ajánlott, mivel a sugárfogó marker a ballon közepén helyezkedik el, ezáltal megnehezíti a precíz pozicionálást, valamint az OTW-ballonok fizikai tulajdonságai sem alkalmasak az okklúzión történő áthatolásra.

\section{Extenziós katéterek}

Ezen eszközök használata (Guidezilla [Boston Scientific, Natick, MA, USA]; GuideLiner [Teleflex, Wayne, PA, USA]) - amelyet az angol nomenklatúra "motherand-child" technikaként tart számon (34) - növeli azt a koaxiális erőt, amelyet a drót kifejthet a kalcifikált szövetre. Az extenziós katéterek mindemellett elősegítik a különböző eszközök lejuttatását is distalis léziók vagy kanyarulatos proximális koronáriák esetén, így csökkentik a koszorúér-szájadékok disszekciójának a mély vezetőkatéter inkubációból származó veszélyét. Extrém távolságok, vagy tortuozitás esetén többszöri extenziós katéter használata is lehetséges - amely teleszkópos technikaként is ismert (angol nomenklatúrában „mother-daughter-granddaughter” technika) (35) - azonban ez mindenképp $8 \mathrm{~F}$ vezetőkatéter használatához kötött.

\section{Horgonyzó technikák}

Számos horgonyzó technika elérhető, amelyek célja ugyancsak a vezetőkatéter szupportjának növelése. A horgonyzás általános koncepciója, hogy egy második levezetett vezetődróton keresztül ballont fújunk fel, amely a vezetőkatétert az ér szájadékában "lehorgonyozza”. E technikának több formája létezik: az okklúziótól proximálisan elhelyezkedő oldalágban (oldalág horgony) (36); az okklúziótól proximálisan a fóérben (koaxiális horgony (37) - a ballon rögzíti a mikrokatétert is az érfalhoz); az okklúziótól distalisan (distalis horgony (38) a vezető drót átjutását követően, amely elsősorban a stent lejuttatását segítheti); vagy a subintimalis térben (subintimalis horgony) (39). A horgonyzás alkalmazása esetén figyelembe kell vennünk az oldalágakban okozott érsérülés vagy az okklúzió miatti hosszan tartó iszkémia veszélyét.

Megfelelő támaszték biztosítása esszenciális a vezetódrót penetrációs képességének javítása érdekében, amelyhez a lehető legnagyobb átméröjü katéterek használata javasolt. Mikrokatéterek minden CTO-intervenció esetében rutinszerüen alkalmazandóak. Egyéb technikák, mint például az extenziós katéterek vagy horgonyzási technikák további segítséget nyújthatnak a koaxiális erö növelése érdekében.

\section{A vezetődrót előkészítése és drótozási technikák}

Az anterográd drót eszkalációs technika 4 fő fázisból áll, amely $a z$ 
- okklúzió proximális sapkájához való eljutást,

- a proximális sapka penetrációját,

- a drót okklúzióban történő navigációját, és

- a distalis valódi lumenbe jutást jelenti.

\section{A CTO megközelítése}

A speciális CTO-vezetődrót és a mikrokatéter atraumatikus lejuttatása a proximális sapkához reguláris intervenciós drótok segítségével történik. Ezzel elkerülhetjük a proximális érszakasz sérülését, továbbá a dedikált CTO-drót görbületének útközbeni torzulását. A proximális sapkát elérve a mikrokatéter e drótra rávezethető, és ott az eredeti drót a speciális CTO-vezetődrótra kicserélhető. Eközben mikrokatéter tip-injekció egyes esetekben további információt nyújthat a proximális sapka anatómiájáról.

\section{A proximális sapka penetrációja}

A vezetődrót megválasztását elsősorban a proximális sapka anatómiája határozza meg. Abban az esetben, ha az ér lefutása jól követhető (rövid, egyenes érszakasz), merev kúpos végű drótok a választandóak (Gaia $2^{\text {nd }}$, vagy igen kemény sapka esetén Confianza Pro 12 [Asahi Intecc. Nagoya, Japán]), ugyanakkor, ha az ér architektúrája nem egyértelmü, kevésbé merev, polimer bevonatú (Fielder XT család [Asahi Intecc. Nagoya, Japán], vagy Pilot 200 [Abbott Laboratories, Chicago, US]) vagy polimer bevonat nélküli drótok (Ultimate Bros 3, Miracle [Asahi Intecc. Nagoya, Japán]) képesek az ér lefutását megfelelően követni. Az ideális vezetődrót görbület a proximális sapka penetrációjához az $1 \mathrm{~mm}$ hosszú $30-45^{\circ}$ szöget bezáró, amely maximális penetrációs kapacitás mellett a mikrocsatornák útvonalát is megfelelöen követni tudja csökkentve a subintimalis térbe jutás esélyét. A proximális sapka extrém kalcifikációja esetén a drót rotáció nélküli szúró jellegủ előre mozgatása (penetrációs technika) is eredményes lehet.

\section{A vezetődrót navigációja az okklúzióban}

A proximális sapka sikeres áttörését követően az okkludált szegmenten belül történő manipuláció eltérő technikát igényel, amely gyakori drótcserével is járhat (eszkaláció/deeszkaláció). A „sliding” technika, amely mérsékelt rotációs mozgás és penetrációval kombinált drótozást jelent, polimer bevonatú drótokkal eredményes lehet, ugyanakkor rezisztens léziók esetén erőteljesebb rotációs mozgás "drilling technika” válhat szükségessé. A „drilling-technikához” a Gaia-vezetődrót család az ideális választás (Gaia $1^{\text {st }}, 2^{\text {nd }}, 3^{\text {rd }}$ ) mivel ezen drótok mikrostruktúrája megfelelő manőverezési képességet biztosít még a hosszú és tortuózus érszakaszok esetén is minimalizálva a perforáció esélyét.

\section{Behatolás a valódi lumenbe}

Miután a vezetődrót elérte a distalis sapka síkját, mérsékelten (Gaia család, Ultimate Bros 3, Miracle 6) vagy kifejezetten merev (Confianza Pro 12) végü drót használata eredményezheti a valódi lumenbe jutást, ugyanakkor a distalis drót pozíciónak a megerősítése nagyon lényeges, hiszen esetleges perforáció dróttal többnyire nem veszélyes, ugyanakkor mikrokatéterrel vagy ballonnal perikardiális tamponádot okozhat. A drót valódi lumen pozíciójának megerősítése többnyire kontralaterális angiogáfiával történik. Ha a bejuttatott mikrokatéterből vért tudunk aspirálni, vagy nyomásgörbe detektálható a mikrokatéteren keresztül, az szintén kisegítő információt nyújthat az intraluminalis pozícióról.

\section{"Trapping" technika}

Az esetek jelentős többségében több, különböző penetrációs készségű vezetődrótra is szükség lehet. llyen esetekben szükséges lehet a mikrokatéter eltávolítása az első drót helyben hagyásával. A „trapping” technika során egy segédballont fújunk fel a vezetőkatéteren belül $(2,0 \mathrm{~mm}$ átmérőjű 6 F-hez, $2,5 \mathrm{~mm}$ átmérőjű 7 F-hez). Ez hozzápréseli a vezetődrótot a katéter falához stabilizálva annak pozícióját a mikrokatéter eltávolításához. Erre a célra fejlesztett speciális ballonok előnye (Trapper, Boston Scientific, Natick, MA, USA), hogy igen alacsony profiljuk kevés helyet foglal el, továbbá megegyező hosszúságúak a vezetőkatéterével, így fluoroszkópia nélkül is biztonságosan behelyezhetők a koronária sérülésének elkerülésével.

Vezetődrótok tudatos megválasztása, előkészítése, és a drótozási manőverek megfelelő alkalmazása alapvető fontosságú a sikeres CTO PCl érdekében. A drótpozíció megtartása kritikus a dróteszkaláció és deeszkaláció során, ezért a trapping technika elsajátítása és megfelelő alkalmazása fontos részét képezi az anterográd CTO-operatörök gyakorlatának.

Speciális anterográd drótozási technikák Ideális esetben az anterográd eszkalációs technika sikeres (7. ábra, $A$ panel), mindazonáltal az esetek jelentékeny hányadában a drót a subintimalis térbe jut, ahonnan igen nehéz és sokszor csak nagy gyakorlattal lehetséges a visszavezetésük a lumen felé. $E$ célból a drót végét újra kell formáznunk, ekkor $70-90^{\circ}$-os 2-3 mm hosszú görbületet képezünk. Ki kell emelnünk ugyanakkor, hogy subintimalis pozíció esetén a legjobb eredményt a dedikált anterográd disszekció re-entry technika alkalmazása adja erre specializált eszközökkel (CrossBoss mikrokatéter, Stingray ballon [mindkettö Boston Scientific, Natick, MA, USA]) (40). A csupán dróttal történő ún. random re-entry technika azzal a veszéllyel jár, hogy nagy subintimalis haematomát képezünk, ezután már egyre nehezebb a valódi lumenbe jutás. A hosszú szakaszon subintimalis stentelés pedig magas restenosis és reokklúziós rátát okozhat (41, 42). A dedikált re-entry eszközökön kívül is lehetséges azonban a distalis valódi lumenbe visszajutás a következő eljárások alkalmazásával. 
A

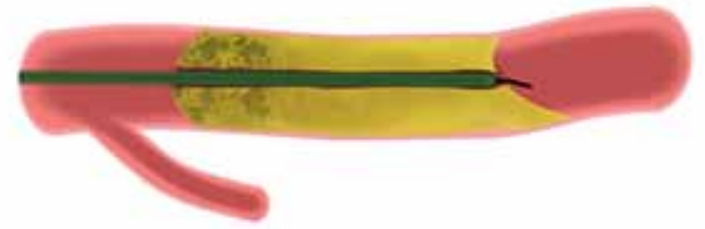

$\mathrm{B}$

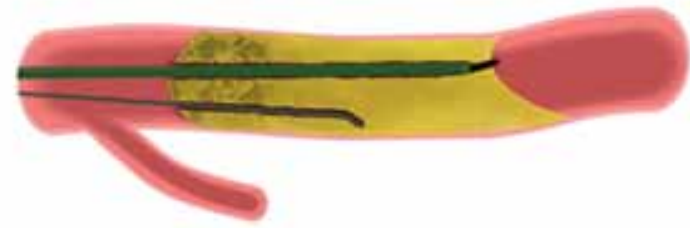

C

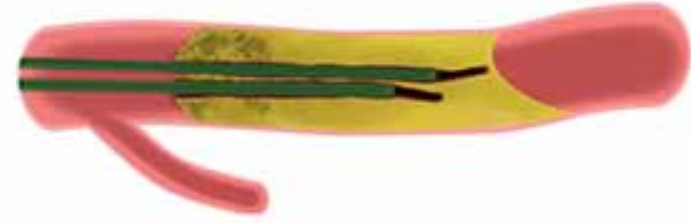

D

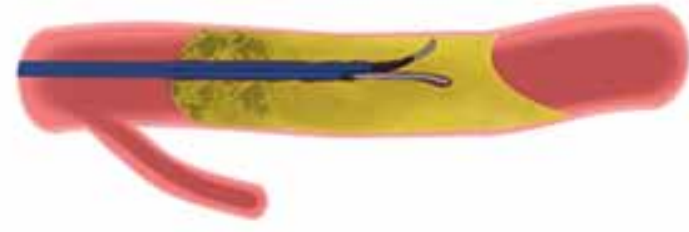

E

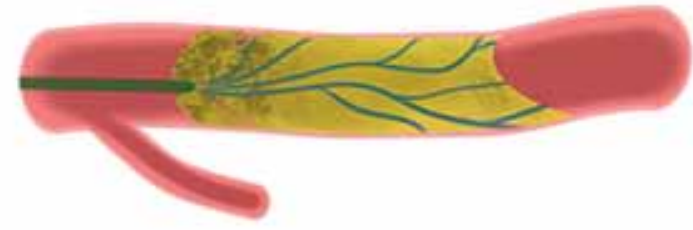

7. ÁBRA. Speciális anterográd drótozási technikák: eszkalációs technika (A); paralleldrótozás (B); „libikóka technika” (C); kettős lumenú mikrokatéter technika (D); mikrocsatorna ('Carlino') technika (E)

\section{Paralleldrótozási technika (43)}

Abban az esetben, ha az első vezetődrót helyzete subintimalisnak sejthető, annak helyben hagyása (mikrokatéter nélkül) mellett egy második vezetődrót szimultán felvezetése - parallel helyzetben az elsőhöz képest (7. ábra, B panel) - elősegítheti második vezetődrót intraluminalis vezetését azáltal, hogy a helyben hagyott első drót kiegyenesíti az adott érszakaszt, valamint meggátolja hogy a második drót ugyanazt a fals utat kövesse. Kettőnél több vezetődrót is használható, ugyanakkor ez jelentősen megnehezítheti az angiográfiás tájékozódást.

\section{"Libikóka technika” (43)}

A libikóka technika egy módosított paralleldrótozási eljárás, amely során az első vezetődrót és mikrokatéter a subintimalis térben marad, mellé pedig egy második mikrokatéter-vezetődrót együttest vezetünk az okklúzióba. Ezen két mikrokatéter segítségével felváltva manipulálhatunk a két dróttal (7. ábra $C$ panel). Ilyen esetben második drótként érdemes merev, de könnyen irányítható eszközöket választani, mint a Gaia-vezetődrótok, vagy a Miracle 6, illetve 12.

\section{Kettős lumenü mikrokatéterek (44)}

A kettős lumenű mikrokatéterek alkalmazása kezdeti subintimalis drótpozíció felvétele során ideális opcióként szolgálnak a második vezetődrót helyes irányba juttatásához (7. ábra D-panel). Ezen mikrokatéterek monorail- (distalis) és over-the-wire (proximális) portot tartalmaznak. Ha a primer vezetődrót subintimalis pozícióba jut, a mikrokatétert trapping technikával kettős lumenű katéterre cserélhetjük, majd az oldalsó proximális porton keresztül (over-the-wire) a szekunder vezetődrót intraluminalis drót manipulációra használható. A kettős lumenü mikrokatéterek használata ugyancsak jelentős szerepet játszik a bifurkációs okklúziók oldalágának rekanalizációjában.

\section{Szezám tárulj technika" (45)}

Ezen metódus csak olyan CTO-anatómia esetében alkalmazható, ahol az okklúzió közvetlenül distalisan kezdődik az oldalágtól. A „szezám tárulj technika” lényege, hogy az oldalágba jutott vezetődróton ballonnal tágítást végzünk, amely módosítja az okklúzió architektúráját elősegítvén a második vezetődrót könnyebb bevezetését a distalis valódi lumen felé. Mindazonáltal ez a technika csak egy speciális koronária-anatómia esetén alkalmazható, valamint a subintimalis drótozás esélye is magasabb („side-BASE technika”) (46), amely így jelentős mértékben korlátozza ennek a technikának széles körü alkalmazhatóságát.

\section{Mikrocsatorna-technika („Carlino technika") (47)}

A mikrocsatorna-technika lényege a mikrokatéter okklúzióba vezetése, majd finoman 0,5-1,0 ml kontrasztanyag injektálása az okklúzió testébe, amely kontrollált hidraulikus disszekciót okoz a mikrocsatornák mentén elősegítve az okklúzió „felpuhítását”, valamint a koronária lefutásának feltérképezését (7. ábra, $E$ panel). A Carlino-technika eredendően anterográd drót eszkaláció elősegítésére lett fejlesztve, azonban ez gyakran a subintimalis tér megnyitásával is járhat, amely a dedikált disszekciós re-entry technikák alkalmazását követeli meg (Stingray-ballon), így ez a technika csak megfelelő intervenciós gyakorlattal alkalmazható biztonságosan.

Komplex anterográd technikák alkalmazásának elsajátítása jelentős tapasztalatot és megfelelő eszköztárat igényel a biztonságos használathoz, azonban e módszerek hasznos stratégiaként szolgálnak, ha a vezetődrót subintimalis pozícióba jutott. Subintimalis drótozás, és dedikált re-entry eszközök nélküli anterográd disszekció és re-entry technika (klasszikus STAR-technika) klinikai alkalmazását nem javasoljuk a mai intervenciós gyakorlatban a magas restenosis és reokklúziós ráta miatt. 


\section{A rekanalizáció befejező lépései}

Amint a vezetődrót a distalis valódi lumenbe jutott, és annak intraluminalis pozíciójáról meggyőződtünk, a mikrokatéteren át a drót cseréje következik hagyományos vezetődrótra, célszerűen extra szupport drótra (Sion Blue ES, BHW, Grand Slam). Ennek a lépésnek jelentősége, hogy a CTO-vezetődrótok distalis vége jó penetrációs képességü, így könnyen okozhatnak distalis perforációt. E ponttól az intervenció az angioplasztika általánosan ismert lépéseinek megfelelően zajlik (ballon predilatáció és stentimplantáció), ugyanakkor az esetek kis százalékában a ballon felvezetése („balIoon unrossable" léziók [az esetek 6-8\%-ában, sikeres distalis drótozást követően]) $(48,49)$ és a léziónak megfelelő expanziója („,balloon undilatable” léziók [esetek 12\%-a sikeres distalis drótozást követően]) (50) sikertelen, amely megakadályozhatja a rekanalizált érszakasz stentelését. A ballonnal átjárhatatlan vagy tágíthatatlan léziók megoldása gyakran speciális technikákat igényelnek - mint például „grenadoplasztika” (azaz kicsiny ballon szándékosan előidézett ruptúrája a proximális sapka szintjében), lézerkatéter, rotációs arterectomia, vagy különböző „cutting” ballonok (spirális vagy paralel vágópengékkel felszerelt ballonok). Ezen eszközök, eljárások helyes algoritmus szerinti alkalmazása az esetek nagy részében lehetővé teszi az intervenciók biztonságos és hatékony befejezését (29).

A speciális CTO-vezetődrótok cseréje fontos lépés a ballon és a stent levezetését megelőzően, ezzel minimálisra csökkentjük a vezetődrót-okozta traumatikus distalis érsérülés lehetőségét. Az angioplasztika az esetek nagy többségében ezután konvencionális módon kivitelezhető, azonban anterográd rekanalizációk esetében a nagyobb és körkörös plakktömeg miatt egyéb plakk-modifikációs technikák használata is szükséges lehet a balIon vagy stentek kihelyezéséhez és megfelelö expanziójához.

\section{Következtetések}

Anterográd CTO-rekanalizációs technikák széles körben és hatékonyan alkalmazhatóak a mai CTO-intervenciós gyakorlatban, így ezen szemlélet és gyakorlat megszerzése és alkalmazása a CTO-tréning egyik legfontosabb lépése, továbbá alapul szolgál a komplex retrográd és anterográd disszekciós re-entry technikák elsajátításához is.

\section{Irodalom}

1. Fefer $P$, Knudtson ML, Cheema $A N$, et al. Current perspectives on coronary chronic total occlusions: the Canadian Multicenter Chronic Total Occlusions Registry. J Am Coll Cardiol 2012; 59: 991-7. doi: 10.1016/j.jacc.2011.12.007

2. Jeroudi OM, Alomar ME, Michael TT, et al. Prevalence and ma- nagement of coronary chronic total occlusions in a tertiary Veterans Affairs hospital. Catheter Cardiovasc Interv 2014; 84: 637-43. doi: 10.1002/ccd. 25264

3. Christofferson RD, Lehmann KG, Martin GV, Every N, Caldwell $\mathrm{JH}$, Kapadia SR. Effect of chronic total coronary occlusion on treatment strategy. Am J Cardiol 2005; 95: 1088-91. doi: 10.1016/j.amjcard.2004.12.065

4. Ramunddal T, Hoebers LP, Henriques JP, et al. Chronic total occlusions in Sweden - a report from the Swedish Coronary Angiography and Angioplasty Registry (SCAAR). PLoS One 2014; 9 : e103850. doi. 10.1371/journal.pone.0103850

5. Azzalini L, Jolicoeur EM, Pighi M, et al. Epidemiology, Management Strategies, and Outcomes of Patients With Chronic Total Coronary Occlusion. Am J Cardiol 2016; 118: 1128-1135. doi: 10.1016/j. amjcard.2016.07.023

6. Tajti P, Karmpaliotis D, Alaswad K, et al. The Hybrid Approach to Chronic Total Occlusion Percutaneous Coronary Intervention: Update From the PROGRESS CTO Registry. JACC Cardiovasc Interv 2018. doi: 10.1016/j.jcin.2018.02.036

7. Wilson WM, Walsh SJ, Yan AT, et al. Hybrid approach improves success of chronic total occlusion angioplasty. Heart 2016; 102 : 1486-93. doi: 10.1136/heartjnl-2015-308891

8. Maeremans J, Walsh S, Knaapen P, et al. The Hybrid Algorithm for Treating Chronic Total Occlusions in Europe: The RECHARGE Registry. J Am Coll Cardiol 2016; 68: 1958-1970. doi: 10.1016/j. jacc.2016.08.034

9. Habara M, Tsuchikane E, Muramatsu T, et al. Comparison of percutaneous coronary intervention for chronic total occlusion outcome according to operator experience from the Japanese retrograde summit registry. Catheter Cardiovasc Interv 2016; 87: 1027-35. doi: $10.1002 /$ ccd. 26354

10. Werner G. A Randomized Multicentre Trial to Evaluate the Utilization of Revascularization or Optimal Medical Therapy for the Treatment of Chronic Total Coronary Occlusions (EuroCTO). EuroPCR 2017. Paris, 2017. doi: 10.1093/eurheartj/ehy220

11. Sapontis J, Salisbury AC, Yeh RW, et al. Early Procedural and Health Status Outcomes After Chronic Total Occlusion Angioplasty: A Report From the OPEN-CTO Registry (Outcomes, Patient Health Status, and Efficiency in Chronic Total Occlusion Hybrid Procedures). JACC Cardiovasc Interv 2017; 10: 1523-1534. doi: 10.1016/j. jcin.2017.05.065

12. Hannan EL, Zhong Y, Jacobs AK, et al. Patients With Chronic Total Occlusions Undergoing Percutaneous Coronary Interventions: Characteristics, Success, and Outcomes. Circ Cardiovasc Interv 2016; 9: e003586. doi: 10.1161/CIRCINTERVENTIONS.116.003586 13. Brilakis ES, Banerjee S, Karmpaliotis D, et al. Procedural Outcomes of Chronic Total Occlusion Percutaneous Coronary Intervention: A Report From the NCDR (National Cardiovascular Data Registry). JACC Cardiovasc Interv 2015; 8: 245-53. doi: 10.1016/j. jcin.2014.08.014

14. Tajti P, Burke MN, Karmpaliotis D, et al. Update in the Percutaneous Management of Coronary Chronic Total Occlusions. JACC Cardiovasc Interv 2018; 11: 615-625. doi: 10.1016/j.jcin.2017.10.052 15. Morino $\mathrm{Y}$, Abe M, Morimoto $\mathrm{T}$, et al. Predicting successful guidewire crossing through chronic total occlusion of native coronary lesions within 30 minutes: the J-CTO (Multicenter CTO Registry in Japan) score as a difficulty grading and time assessment tool. JACC Cardiovasc Interv 2011; 4: 213-21. doi: 10.1016/j.jcin.2010.09.024 16. Alessandrino $G$, Chevalier B, Lefevre T, et al. A Clinical and Angiographic Scoring System to Predict the Probability of Successful First-Attempt Percutaneous Coronary Intervention in Patients With Total Chronic Coronary Occlusion. JACC Cardiovasc Interv 2015; 8: 1540-8. doi: 10.1016/j.jcin.2015.07.009

17. Christopoulos G, Kandzari DE, Yeh RW, et al. Development and Validation of a Novel Scoring System for Predicting Technical Success of Chronic Total Occlusion Percutaneous Coronary Interventions: The PROGRESS CTO (Prospective Global Registry for the Study of Chronic Total Occlusion Intervention) Score. JACC Cardiovasc Interv 2016; 9: 1-9. doi: 10.1016/j.jcin.2015.09.022 
18. Galassi AR, Boukhris M, Azzarelli S, Castaing M, Marza F, Tomasello SD. Percutaneous Coronary Revascularization for Chronic Total Occlusions: A Novel Predictive Score of Technical Failure Using Advanced Technologies. JACC Cardiovasc Interv 2016. doi: 10.1016/j.jcin.2016.01.036

19. Maeremans J, Spratt JC, Knaapen P, et al. Towards a contemporary, comprehensive scoring system for determining technical outcomes of hybrid percutaneous chronic total occlusion treatment: The RECHARGE score. Catheter Cardiovasc Interv 2017. doi: 10.1002/ ccd. 27092

20. Ellis SG, Burke MN, Murad MB, et al. Predictors of Successful Hybrid-Approach Chronic Total Coronary Artery Occlusion Stenting: An Improved Model With Novel Correlates. JACC Cardiovasc Interv 2017; 10: 1089-1098. doi: 10.1016/j.jcin.2017.03.016

21. Danek BA, Karatasakis A, Karmpaliotis D, et al. Development and Validation of a Scoring System for Predicting Periprocedural Complications During Percutaneous Coronary Interventions of Chronic Total Occlusions: The Prospective Global Registry for the Study of Chronic Total Occlusion Intervention (PROGRESS CTO) Complications Score. J Am Heart Assoc 2016; 5. doi: 10.1161/ JAHA.116.004272

22. Tanaka $\mathrm{H}$, Morino $\mathrm{Y}$, Abe M, et al. Impact of J-CTO score on procedural outcome and target lesion revascularisation after percutaneous coronary intervention for chronic total occlusion: a substudy of the J-CTO Registry (Multicentre CTO Registry in Japan). Eurolntervention 2016; 11: 981-8. doi: 10.4244/EIJV11I9A202

23. Christopoulos G, Wyman RM, Alaswad K, et al. Clinical Utility of the Japan-Chronic Total Occlusion Score in Coronary Chronic Total Occlusion Interventions: Results from a Multicenter Registry. Circ Cardiovasc Interv 2015; 8: e002171. doi: 10.1161/CIRCINTERVENTIONS.114.002171

24. Nombela-Franco L, Urena M, Jerez-Valero M, et al. Validation of the J-chronic total occlusion score for chronic total occlusion percutaneous coronary intervention in an independent contemporary cohort. Circ Cardiovasc Interv 2013; 6: 635-43. doi: 10.1161/CIRCINTERVENTIONS.113.000447

25. Azzalini L, Brilakis ES. Ipsilateral vs. contralateral vs. no collateral (antegrade only) chronic total occlusion percutaneous coronary interventions: What is the right choice for your practice? Catheter Cardiovasc Interv 2017; 89: 656-657. doi: 10.1002/ccd.27005

26. Karatasakis A, Danek BA, Karmpaliotis D, et al. Comparison of various scores for predicting success of chronic total occlusion percutaneous coronary intervention. Int J Cardiol 2016; 224: 50-56. doi: $10.1016 /$ j.ijcard.2016.08.317

27. Brilakis ES, Grantham JA, Rinfret S, et al. A percutaneous treatment algorithm for crossing coronary chronic total occlusions. JACC Cardiovasc Interv 2012; 5: 367-79. doi: 10.1016/j.jcin.2012.02.006

28. Harding SA, Wu EB, Lo S, et al. A New Algorithm for Crossing Chronic Total Occlusions From the Asia Pacific Chronic Total Occlusion Club. JACC Cardiovasc Interv 2017; 10: 2135-2143. doi: 10.1016/j.jcin.2017.06.071

29. Brilakis E. Manual of Coronary Chronic Total Occlusion Interventions: A Step-by-Step Approach. $2^{\text {nd }}$ ed. 2017.

30. Kinnaird T, Anderson R, Ossei-Gerning N, et al. Vascular Access Site and Outcomes Among 26,807 Chronic Total Coronary Occlusion Angioplasty Cases From the British Cardiovascular Interventions Society National Database. JACC Cardiovasc Interv 2017; 10: 635-644. doi: 10.1016/j.jcin.2016.11.055

31. Marquis-Gravel G, Tremblay-Gravel M, Levesque J, et al. Ultrasound guidance versus anatomical landmark approach for femoral artery access in coronary angiography: A randomized controlled trial and a meta-analysis. J Interv Cardiol 2018; 31: 496-503. doi: 10.1111/joic. 12492

32. Fairley SL, Lucking AJ, McEntegart M, et al. Routine Use of Fluoroscopic-Guided Femoral Arterial Puncture to Minimise Vascular Complication Rates in CTO Intervention: Multi-centre UK Experience. Heart Lung Circ 2016; 25: 1203-1209. doi: 10.1016/j. hlc.2016.04.006
33. Rinfret $S$, Joyal D, Nguyen CM, et al. Retrograde recanalization of chronic total occlusions from the transradial approach; early Canadian experience. Catheter Cardiovasc Interv 2011; 78: 366-74. doi. $10.1002 / \mathrm{ccd} .23140$

34. Takahashi S, Saito S, Tanaka S, et al. New method to increase a backup support of a 6 French guiding coronary catheter. Catheter Cardiovasc Interv 2004; 63: 452-6. doi: 10.1002/ccd.20223

35. Finn MT, Green P, Nicholson W, et al. Mother-Daughter-Granddaughter Double GuideLiner Technique for Delivering Stents Past Multiple Extreme Angulations. Circ Cardiovasc Interv 2016; 9. doi: 10.1161/CIRCINTERVENTIONS.116.003961

36. Fujita S, Tamai H, Kyo E, et al. New technique for superior guiding catheter support during advancement of a balloon in coronary angioplasty: the anchor technique. Catheter Cardiovasc Interv 2003; 59: 482-8. doi: 10.1002/ccd.10551

37. Fang HY, Wu CC, Wu CJ. Successful transradial antegrade coronary intervention of a rare right coronary artery high anterior downward takeoff anomalous chronic total occlusion by double-anchoring technique and retrograde guidance. Int Heart J 2009; 50 : 531-8. doi: 10.1536/ihj.50.531

38. Mahmood A, Banerjee S, Brilakis ES. Applications of the distal anchoring technique in coronary and peripheral interventions. J Invasive Cardiol 2011; 23: 291-4.

39. Michael TT, Banerjee S, Brilakis ES. Subintimal distal anchor technique for "balloon-uncrossable" chronic total occlusions. J Invasive Cardiol 2013; 25: 552-4.

40. Danek BA, Karatasakis A, Karmpaliotis D, et al. Use of antegrade dissection re-entry in coronary chronic total occlusion percutaneous coronary intervention in a contemporary multicenter registry. Int $\mathrm{J}$ Cardiol 2016; 214: 428-437. doi: 10.1016/j.jicard.2016.03.215

41. Valenti R, Vergara R, Migliorini A, et al. Predictors of reocclusion after successful drug-eluting stent-supported percutaneous coronary intervention of chronic total occlusion. J Am Coll Cardiol 2013; 61: 545-50. doi: 10.1016/j.jacc.2012.10.036

42. Azzalini L, Dautov R, Brilakis ES, et al. Procedural and Ionger-term outcomes of wire- versus device-based antegrade dissection and re-entry techniques for the percutaneous revascularization of coronary chronic total occlusions. Int J Cardiol 2017; 231: 78-83. doi: 10.1016/j.ijcard.2016.11.273

43. Rathore $S$, Matsuo H, Terashima M, et al. Procedural and in-hospital outcomes after percutaneous coronary intervention for chronic total occlusions of coronary arteries 2002 to 2008: impact of novel guidewire techniques. JACC Cardiovasc Interv 2009; 2: 489-97. doi: 10.1016/j.jcin.2009.04.008

44. Chiu CA. Recanalization of difficult bifurcation lesions using adjunctive double-lumen microcatheter support: two case reports. J Invasive Cardiol 2010; 22: E99-103.

45. Saito S. Open Sesame Technique for chronic total occlusion. Catheter Cardiovasc Interv 2010; 75: 690-4. doi: 10.1002/ccd. 22316 46. Roy J, Hill J, Spratt JC. The "side-BASE technique": Combined side branch anchor balloon and balloon assisted sub-intimal entry to resolve ambiguous proximal cap chronic total occlusions. Catheter Cardiovasc Interv 2017. doi: $10.1002 /$ ccd. 27422

47. Carlino M, Latib A, Godino C, Cosgrave J, Colombo A. СTO recanalization by intraocclusion injection of contrast: the microchannel technique. Catheter Cardiovasc Interv 2008; 71: 20-6. doi: $10.1002 /$ ccd. 21396

48. Patel SM, Pokala NR, Menon RV, et al. Prevalence and treatment of "balloon-uncrossable" coronary chronic total occlusions. J Invasive Cardiol 2015; 27: 78-84.

49. Karacsonyi J, Karmpaliotis D, Alaswad K, et al. Prevalence, indications and management of balloon uncrossable chronic total occlusions: Insights from a contemporary multicenter US registry. Catheter Cardiovasc Interv 2016. doi: $10.1002 / c c d .26780$

50. Tajti P, Karmpaliotis D, Alaswad K, et al. Prevalence, Presentation and Treatment of "Balloon Undilatable" Chronic Total Occlusions: Insights from a Multicenter US Registry. Catheter Cardiovasc Interv 2018; 91: 657-666. doi: 10.1002/ccd.27510 